Youli Ioannesyan

\title{
The St. Petersburg 19th c. Collection of Materials on the Babi and Baha'i Faiths: Primary and other Sources
}

Abstract: The article is concerned with one of the richest collections of materials related to the Babi and Baha'i faiths, the St. Petersburg collection. The large amount of primary sources flowing into pre-revolutionary Russia was distributed between three scholarly and learning centers: the Asiatic Museum, presently the Institute of Oriental Manuscripts, Russian Academy of Sciences (the bulk of the sources), the St. Petersburg State University and the Russian National Library. These materials either in Persian or Arabic take the form of manuscripts and lithographs. The article describes these materials and gives briefly the history of studies of these sources.

Key words: manuscript collections, Babi and Baha'i studies in Russia

\section{Introduction}

The Russian Empire during the 19th c. was highly interested in current events and political changes taking place in Persia, including the events surrounding the appearance of the Babi and Baha'i faiths. Persia has always been a strategic concern of Russia's geopolitical interests and this traditional importance allotted to Iran materialized itself in hundreds if not thousands of documents and writings collected by the pre-revolutionary Russian government. Among these materials constantly flowing into the Russian Empire was information about and original texts belonging to these two emerging religions. Fortunately, this information was supplied regularly and systematized by the Russian diplomats and scholars working in Persia. Among the Russian diplomats were trained Orientalists, who were able to properly appreciate their significance. This paper is a brief introduction to the work carried out and materials collected by these remarkable men.

(C) Youli Arkadyevich Ioannesyan, Institute of Oriental Manuscripts, Russian Academy of Sciences 


\section{Prominent Figures}

The work of gathering, preserving, identifying, classifying, studying, translating and publishing the Babi and Baha'i materials was performed by numerous people, but the most prominent were A.G. Tumanski (18611920), both a scholar and a diplomat, and Baron Victor Rosen (1849-1908), a pure scholar. Other notable figures included scholars such as Professor Valentin Alekseevich Zhukovski and Boris (Johannes Albrecht Bernhard) Dorn, diplomats, such as Fiodor Bakulin, M. Bezobrazoff and the Orientalist Matvei Gamazoff. The latter was the Head of the School of Oriental Languages within the Asian Department of the Ministry of Foreign Affairs of the Russian Empire. A substantial contribution to the collection of manuscripts and especially of lithographs was made by the prominent Iranologist Vladimir Ivanow.

It would be fair to say that Russian scholars became acquainted with the writings of Baha'u'llah before they found out about Baha'u'llah himself. ${ }^{1}$ Russian was the first European language into which the writings of Baha'u'llah, the founder of the Baha'i religion, were translated. First and foremost among these translations is Tumanski's translation of the Most Holy Book by Baha'u'llah (see below).

Rosen, among his many merits, must be given special credit for identifying and describing the manuscripts, as well as for founding and editing a periodical journal, "Proceedings of the Oriental Branch of the (Imperial) Russian Archaeological Society" (ZVORAO), where his and Tumanski's translations of Baha'i texts were published.

Tumanski graduated from the School of Oriental Languages of the Asian Department of the Ministry of Foreign Affairs, where he studied languages under Gamazoff. He ended his career as a major-general in the Russian army, but he was also an Orientalist (Iranologist and Turkologist). The scarcity of biographical information about him might be due to the fact that he left Russia after the Bolsheviks took over in 1917 and was not considered noteworthy by the new regime. He is known to have spent some time in Ashkabad, where he came into close contact with the Baha'i community, and ever since was keenly interested in the Baha'is and their beliefs. He died in emigration on the Princes' Islands (near Constantinople).

It has now been established that as early as 1877 , the first part of the writings of Baha'u'llah was delivered to the Library of the Educational

\footnotetext{
${ }^{1}$ Thus, Tumanski wrote: "Our knowledge of the writings of Baha'u'lah preceded that of himself and his reform" (KITABEAQDES 1899, xxvii-xxviii).
} 
Department of the Ministry of Foreign Affairs (St. Petersburg) by Russia's Consul General in (Persian) Azerbaijan M. Bezobrazoff through Gamazoff. As he was describing the Tablets for a catalogue, Rosen discerned the special character of the 29 Epistles and also spotted their marked difference from the early writings of the Bab. His study of the texts led him to the conclusion that "[a]ll the Epistles should more or less be considered as revelations". ${ }^{2}$

As early as 1877 Rosen described these 29 Tablets (alvah) in Collections Scientifiques and later, in 1890, began to prepare them for publication, along with a number of other Tablets and Epistles by Baha'u'llah, in a substantial volume which came out after his death (see RosEN (ed.) 1908).

Rosen published a detailed description in French of the Babi and Baha'i manuscripts, often illustrated with large extracts from the original texts. ${ }^{3}$ The collection he described would later become known as the Collection of the Asiatic Museum (presently the Institute of Oriental Manuscripts, RAS). Unfortunately, the materials added to the collection after Rosen's death are not included in the aforementioned descriptive catalogue.

\section{The Origin of the Babi and Baha'i Materials in the IOM, RAS Collection}

The majority of Babi and Baha'i materials collected during the 19th $\mathrm{c}$. ended up in St. Petersburg. Eventually, these materials were distributed between the following three centers of learning: the IOM, RAS (originally Asiatic Museum), the Russian National Library and the Oriental Faculty of St. Petersburg State University.

The St. Petersburg collection of Babi and Baha'i sources consists of manuscripts, lithographs and published materials. The most significant of these can be divided between (1) the writings of the Bab, the prophetfounder of the Babi faith who was Baha'u'llah's forerunner; and (2) the writings of Baha'u'llah, the founder of the Baha'i faith. In this paper, I will further divide the materials into two broad groups: 1) Manuscripts or publications of manuscripts of the writings (with and without translations) of the central figures of the Babi and Baha'i faiths as primary sources; 2) Manuscripts and publications of other materials, such as eyewitness accounts and historical documents about the Babi and Baha'i faiths, which I

\footnotetext{
2 "Toutes les lettres devaient être considérées plus ou moinscomme des révélations" (Collections Scientifiques 1877, 192), see also KiTABEAQDes 1899, xxvii.

${ }^{3}$ Collections Scientifiques 1877-91, vols. 1, 2 and 6.
} 
define as other sources. The materials are organized in the following manner: first I list those writings of the Bab which are unpublished, ${ }^{4}$ followed by those of Baha'u'llah which are also unpublished; second, the writings of Baha'u'llah, which have been published; third writings of Baha'u'llah's son - 'Abdu'l-Baha; and fourth the other sources for Babi and Baha'i history.

The majority of the materials below belong to the IOM collection, therefore, unless otherwise indicated, they are kept in the IOM and can be found in three major descriptive catalogues: AKIMUSHKIN et al. 1998, KHALidov (ed.) 1986, SHCHEglova 1975. However, whenever it is necessary to specify the first two catalogues I will refer to them by their abbreviated titles: PMS - The Persian MSs Catalogue, and AMS - The Arabic manuscripts Catalogue. I also make reference to the two descriptive catalogues of lithographed books published by Olimpiada Shcheglova (ShCHEGlova 1975, ShCHEglova 1989). The first number in each listing stands for the sequential number in the relevant catalogue, while the second number in parentheses is the code under which the manuscript or lithograph is registered.

\section{Unpublished Manuscripts and Lithographs, Described or Registered in Catalogues:}

\section{A. The Writings of the Bab - the Forerunner of Baha'u'llah (1819-1850)}

1. The Persian Bayan (Bayan-i-Farsi) ${ }^{5}$ - the major doctrinal work of the Bab. Written in Persian, it comprises 8,000 verses and is divided into nine sections called Vahids (lit. 'units'), of nineteen chapters each, except for the last which has ten chapters. There are 2 manuscripts of the Persian Bayan in the IOM:

a. No. 392 (A 458)-PMS. The manuscript was a gift to the Institute of Oriental Languages from Russia's consul general in Tabriz (Northern Iran) Bezobrazoff, which was delivered on 4 April 1877. The manuscript has a dedicatory note. It consists of $394 \mathrm{ff}$. and contains 9 Vahids. The name of the copyist and the date are not mentioned. This manuscript is described by

\footnotetext{
${ }^{4}$ What I mean by 'published' here is that the text of a particular manuscript or another of the same writing was published or used for a scholarly publication in pre-revolutionary Russia.

${ }^{5}$ Bayan lit. means "explanation, exposition, utterance".
} 
Rosen. ${ }^{6}$ The description is followed by a large extract from the Persian Bayan, containing the whole of the first Vahid. Rosen also included a list of the titles of the remaining eight Vahids of the book. This manuscript is also mentioned by Dorn; ${ }^{7}$

b. No. 393 (Д 439)-PMS. Another manuscript of the Persian Bayan, which was also a gift, this time from Bakulin. It was received on 5 May 1874 , as follows from a note in the manuscript.

The manuscript, though written in a very clear hand, is incomplete. It consists of $98 \mathrm{ff}$. and contains only 7 Vahids, without the name of the copyist and the date. This manuscript is also mentioned by Rosen in his description. ${ }^{8}$

2. The Commentary on the Surih of Josef (Qayyumu'l-Asma') - the first chapter of which was revealed in the presence of Mulla Husayn (the first person to believe in the Bab) on the evening of 22 May 1844. This event marked the Bab's open declaration of his mission. Baha'u'llah described the Qayyumu'l-Asma' as "the first, greatest, and mightiest of all books" of the Bab. Written in Arabic in rhymed prose, it consists of 9,300 verses divided between 111 chapters. Each of the chapters, except for the first, contains a verse from the Surih of Josef in the Koran and the Bab's commentary on it. One whole chapter is titled "The Surih of Josef".

The IOM has 2 manuscripts of the Qayyumu'l-Asma'. Both are beautifully executed, written in a clear hand, and in red ink. Neither bears a title, but their identification as manuscripts of this work by the Bab is beyond any doubt (see below):

a. No. 3169 (C 1167)-AMS. It has $158 \mathrm{ff}$. Not only does it fit the above description of the content of the Qayyumu'l-Asma' (for example, it has on f. $7 \mathrm{a}$ a chapter, titled "The Surih of Josef"), but furthermore on $\mathrm{f} .1 \mathrm{~b}$ the work is referred to as "The Best of Stories" ("Ahsanu'l-Qisas"), which, according to E.G. Browne, is another name for the Qayyumu'l-Asma'. ${ }^{\prime}$ Apart from the copyist's postscript, the manuscript contains a few others which taken together provide a clue to the history of the manuscript. It follows from the copyist's postscript that the manuscript was finished in the month of Shawwal of 1297 A.H. (1880 A.D.). Below is a second postscript in another hand saying: "What the copyist omitted to say is that this noble book

\footnotetext{
${ }^{6}$ Collections Scientifiques 1886, 4-13

${ }^{7}$ Mélanges Asiatiques 1876, 177.

${ }^{8}$ Collections Scientifiques 1886, 3 .

9 Thus, Browne writes: “Ahsanu'l-Kisas, another name for the Bab's Commentary on the Sura-i-Yusuf, also called Kayyumu'l-Asma" (BrownE 1893, 2:398, n. 5). See also BrownE 1892a, 699-01.
} 
was, with God's help, finished by humble, poor, rebellious, [yet] hoping for the Mercy of the Lord, the All-Sufficient, Muhammad Mahdi ibn Karbalayi Shah Karam in... the month of Jumadiu'l-Ula of 1261 of the Hijra (1845 A.D.). May the Lord forgive the copyist, the reader and him who will ask God to forgive the copyist" (translation mine).

As follows from another postscript (in Russian), the manuscript is "a copy made from the original, kept in the Library of Prince "Ali Quli MirzaI'tizadu'l-Saltanih, son of Fath 'Ali Shah, the Minister of Education". It also says that the manuscripts was "a gift from I. Grigorovich, ${ }^{10}$ presented on 12 August 1880 - 17 Ramadan 1297 A.H.”. Thus, putting together all this information, contained in the postscripts, it is fair to conclude that the manuscript dated 1880 was a direct copy of a much earlier manuscript, written in 1845 (only a year after the Bab's proclamation of his mission in 1844!) by a copyist, named Muhammad Mahdi ibn Karbalayi Shah Karam.

b. No. 3070 (B 1141)-AMS. Another MS of the same writing, consisting of $252 \mathrm{ff}$. Unlike the previous manuscript, this is described in detail by Rosen ${ }^{11}$ with the publication of a number of extracts. As Rosen points out, the manuscript is without a title, divided into 111 chapters, each beginning with the words 'In the name of God the Merciful, the Compassionate' and, except for the first chapter, containing a verse from the Koranic Surih of Josef. These characteristics, after comparing the text with Browne's description of a manuscript of the Commentary on the Surih of Josef, enabled Rosen to identify the work as the famous Qayyumu'l-Asma'. In his description, he even traced the Koranic verse in each chapter of the Qayyumu'l-Asma' back to the Koran.

This manuscript was a gift from Bezobrazoff, presented on 4 April 1877. It is undated and has no mention of the copyist.

3. No. 3071 (C 1660)-AMS. A manuscript of 52 ff., consisting of 9 texts in Arabic and 1 in Persian: ff. 1b-24b, 25a-26b, 26b-30a, 30a-31a, 31a$32 \mathrm{a}, 32 \mathrm{~b}-33 \mathrm{~b}, 34 \mathrm{a}-40 \mathrm{~b}, 41 \mathrm{a}-42 \mathrm{a}, 42 \mathrm{~b}-50 \mathrm{~b}, 50 \mathrm{~b}-52 \mathrm{~b}$. It is erroneously designated in AMS as: "Two Surihs from the Koran of the Bab". The style of all parts of this manuscript is that of divine revelations, therefore, they could only proceed from the pen of either the Bab or Baha'u'llah. Only two of these texts have been identified.

The first text can with certainty be identified as part of the Bab's Commentary on the Suriy-i-Baqarih described by Browne. ${ }^{12}$ The manuscript

\footnotetext{
${ }^{10}$ I.G. Grigorovich was chief interpreter of the Russian diplomatic mission in Tehran.

${ }^{11}$ Collections Scientifiques 1877, 179-191.

12 BROWNE 1892a, 498.
} 
contains one third of this commentary. The text on ff. $34 \mathrm{a}-40 \mathrm{~b}$ is titled: "Sahifiy-i-'Adliyyih" (in Persian). Comparison with the Bab's Treatise on Divine Justice has revealed that they are identical, which leads me to the conclusion that the manuscript contains a full text of the said treatise.

f. 1 carries a memorandum from Zhukovski, a date: 1919 and a number: 82.

4. An untitled and undated manuscript in Arabic consisting of $87 \mathrm{ff}$. No. 3073 (A 923)-AMS.

It has a postscript in Russian on the last page, from which it is clear that the manuscript was obtained by Ivanow: "Bought in Isfahan 24/11.VII.1910. W. Ivanow", while a note on the first page probably indicates the year of its joining the collection: 1916.

The manuscript is erroneously registered in AMS as the "[Kitab-i-]Iqan by Baha'u'llah" (The Book of Certitude), which it is not, nor is its author Baha'u'llah. In identifying the text as the Book of the Spirit (Kitab'ur-Ruh), I have been greatly assisted by a British colleague Ismael Velasco. ${ }^{13}$ The text itself contains a reference to the title of the book with a call "to follow it" (f. 17a).

The text, divided into verses in rhymed prose (numbered in red ink), is close in style to the Commentary on the Surih of Josef. A curious note in Persian, definitely not in the copyist's hand, on the inner side of the cover not only dispels the last doubt concerning the non-authorship of Baha'u'llah, but also suggests that the text most likely originated before Baha'u'llah's declaration of his mission: "May God's mercy and the Prophet's praise be on the guardian of the book (hajib-i-kitab) and on its other followers: Azal, Baha', 'Abbas Affandi and the rest...". Based on this note and the mention of the name of 'Abdu'l-Baha ('Abbas Affandi), Velasco has suggested 1863 as the year when this manuscript originated.

5. The Book of Names (Kitab-i-Asma'). Kept in the National Library. The manuscript in Arabic found its way to St. Petersburg in the 19th c. as part of Chanykov's collection (Chanykov was Russia's consul in Tabriz at the time of the Bab's martyrdom there) and was described by Dorn under the wrong title "The Koran of the Babis". ${ }^{14}$ Dorn also provided a printed sample of the text of the manuscript. The transcript is written in the hand of the Bab's amanuensis, ${ }^{15}$ as has recently been confirmed by the Research Department of

\footnotetext{
${ }^{13}$ For more information on this book see, for example, NICOLAS 1905, 213-218.

${ }^{14}$ Mélanges Asiatiques 1868, 279-289.

${ }^{15}$ Dorn states: "Of the above manuscript a Persian Mirza wrote several sheets of paper according to the original and provided diacritical points and vocal signs. In appendix II, I
} 
the Baha'i World Center. This adds to the value of this manuscript, making it one of the oldest transcripts (if not the oldest manuscript) of this book.

Browne was the first to have correctly identified the manuscript as the Kitab-i-Asma ${ }^{16}{ }^{16}$ though until quite recently it was still registered in the library under the incorrect name "the Arabic Bayan". The manuscript is defective, starting only with the 12th Vahid (it lacks Vahids 1-11), but it contains Vahids 12-18, which are missing from Browne's manuscript. The chapters are grouped together according to chapter number and not by Vahids, which only proves that the pages were assembled by people unaware of the structure of the book and the sequence of its parts and subdivisions.

\section{B. The Writings of Baha'u'llah, Prophet Founder of the Baha'i Faith (1819-1892)}

1. The Book of Certitude (Kitab-i-Iqan) - A volume in Persian revealed by Baha'u'llah in Baghdad about two years before his declaration of his mission, which took place in 1863. In it, among other things, Baha'u'llah proclaims and substantiates some key principles of Baha'i teachings, such as the oneness of God and progressive revelation, explains the station and mission of the prophet-founders of world religions, the spiritual meaning of prophecies about the return of Christ, the coming of the Qa'im, and presents the essential qualities of the 'true seeker' of religious truth.

The Book of Certitude is represented in the IOM by a lithograph and 5 manuscripts.

The lithograph was printed in Bombay in 1310 A.H. (1893 A.D.) and is described in the relevant catalogue (code: PsII 164). ${ }^{17}$ This is not the same as the undated lithograph described by Rosen. ${ }^{18}$ However, it accords fully with Rosen's description of the latter in "being executed with utmost care". ${ }^{19}$

Another copy of exactly the same lithographic edition belongs to the Oriental Faculty of St. Petersburg State University and is registered accordingly in its catalogue (code: $\Pi-25 / 4){ }^{20}$

make known the beginning, and I can only add that there can be no doubt about the authenticity of the handwriting as it comes directly from the Secretary of the Báb Himself, which person would have written down this Koran from the recital of his Lord and Master. He had forwarded it from His prison in Tabriz to European hands. The responsibility for the contents rests with the aforesaid secretary" (translation and italics mine - Yu.I.).

${ }^{16}$ BROWNE 1892a, 649-650.

${ }^{17}$ SHCHEGLOVA 1975, 1: 213 .

${ }^{18}$ Rosen 1890, No. 461, Collections Scientifiques 1891, 144.

19 "d'une execution très soignée".

${ }^{20}$ SHCHEGLOVA 1989, 93. 
The five manuscripts of The Book of Certitude which, with one exception, are all dated, are registered in $\mathrm{PMS}^{21}$ under the following sequential numbers and codes (after the code I indicate the date): No. 277 (A 183) - 1296 A.H (1878-79 A.D.); No. 278 (A 461) - 1299 A.H. (1881-82 A.D.); No. 279 (A 1592) - 1305 A.H. (1887-88 A.D.); No. 280 (B 1143) - undated; No. 281 (C 1168) - 1291 A.H. (1874-75 A.D.), while B 1143 and A 461 were also described by Rosen (the former being described in detail and illustrated by large extracts from the text). ${ }^{22}$ Only two of these, namely A 183 and A 1592, have a copyist's postscript, which indicates the copyist's name: Mirza Muhammad Tabrizi and Abdu'l-Zalil Abu Talib Nihavandi respectively. ${ }^{23}$ I have collated the manuscripts with the lithograph and published the results in a supplement to my academic translation of The Book of Certitude into Russian, which came out earlier. ${ }^{24}$ The main conclusion of my research is the following: though the lithograph, on the one hand, and the manuscripts, on the other, do reflect slightly different versions, the differences are very insignificant and even those few instances which cannot be attributed to copyists' errors do not have any effect on the meaning of the sentence and still less on the book as a whole.

The most beautifully and carefully executed are manuscripts A 183 and A 461, both follow a common pattern.

2. Bahayiyih. No. 384 (C 1168-a)-PMS. This is a volume of $60 \mathrm{ff}$., registered in PMS under the general title: Bahayiyih. It contains 4 short epistles in Arabic (ff. $1 \mathrm{a}-2 \mathrm{a} ; 2 \mathrm{a}-3 \mathrm{~b} ; 3 \mathrm{~b}-7 \mathrm{a} ; 7 \mathrm{a}-13 \mathrm{~b}$ ) and a much longer one in Persian (ff. 13b-60b). Of this last PMS says that "the treatise deals with and elaborates on issues explained in the other Baha'i work - [the Kitab-iIqan]. It is composed in the form of an epistle". All the epistles are written in Baha'u'llah's style, although only in the one in Persian, which is written in answer to the question "how it was possible for the Supreme Letters to be turned into those who were doomed to the bottom of hell (Sajjin)", does Baha'u'llah mention his own name - Husayn and refer to the Bayan of the $\mathrm{Bab}$ as "[having been] sent down from the Heaven of My previous Manifestation" (f. 16a). The addressee is mentioned by name once - "Ali (f. 22b), while there is also one reference to Jinab Siyyid Jawad (f. 26a).

One of the texts makes mention of "this great prison" (f. $7 b$ ).

\footnotetext{
${ }^{21}$ AKIMUSHKIn et al. 1998, 1: 66-67.

${ }^{22}$ For the former see Collections Scientifiques 1886, 32-51, for the latter - Collections Scientifiques 1891, 143.

${ }^{23}$ It is hard to tell whether Abdu'l-Zalil ('the abject slave') is part of the name proper or an epithet.

${ }^{24}$ BAHA'U'LLAH 2001.
} 
3. Lawh-i-Babi. No. 3072 (A185) AMS. This single-folio epistle in Arabic contains a text with a beautifully decorated ornamental frame and has an intriguing history. The epistle is registered in AMS as "Lawh-i-Babi". It is not described in Collections Scientifiques, probably because it was received after Rosen's death. It was contained in an envelope with several explanatory notes (in Russian) on separate sheets of paper enclosed together with the manuscript. One note, probably written by Tumanski, says that the epistle "is undoubtedly of Babi origin", "obscure in language and mystical in nature", "is composed in rhymed prose", "its author is definitely Baha'ullah", "containing, quite probably, some historical allusions in the end", "every second phrase in the epistle invariably has the refrain: 'fa subhana rabbi-l'ala", which "in one instance only is replaced by: 'fa subhanarabbana-l'ala". "From the viewpoint of its language and style it is most similar to the Alvah-i-Salatin and to the Suriy-i-Haykal". The author of the note cites certain phrases from this epistle and the aforementioned Tablets of Baha'ullah to highlight this similarity.

Another, much shorter explanatory note, written by another person, tells us a little about the history of this epistle in Russia: "Assistant Professor Khilinski, uncle of General von... [a German name, not clearly written] brought from Mashhad [the name of this city is written in Persian] [and] presented as a gift the letter of... himself". The name preceding the word "himself" could be read as "Baha". If this assumption is correct, the writer of this note thought the epistle to be in Baha'u'llah's own hand. This impression is confirmed by the logical emphasis on the word "himself" which would not be the case if the words merely implied that the epistle was a work by Baha'u'llah.

Also enclosed in the envelope is a visiting card belonging to "Konstantin Vladimirovich Khilinski".

The manuscript presumably entered the manuscript collection in the 1890s.

Further study showed that the epistle was a famous Tablet of Baha'u'llah: The Tablet of the Holy Mariner (Lawh-i-Mallah-i-Quds) in Arabic, revealed on 26 March 1863, only a month before Baha'u'llah's declaration of his mission. A comparison of the manuscript with a photograph of the manuscript of the same Tablet, kept in the Baha'i World Centre, showed that both were in the same hand. Since the manuscript in Haifa was copied by 'Abdu'l-Baha, the manuscript in St. Petersburg must also have been written by 'Abdu'l-Baha. This conclusion was later confirmed by the Research Department of the Baha'i World Centre. In certain instances the St. Petersburg text is closer to the English translation of the Tablet by Shoghi Effendi than that of the manuscript in Haifa. 
4. Baha'i prayers in Arabic. No. 3077 (A 182) AMS. It has $164 \mathrm{ff}$. and (f. 1a.) contains an explanatory note by Rosen: "Brought from Astrabad by L.P. Grigoryev on 1 June [18]92. Signature: V. Rosen".

A paper tag is stuck to f. 1a, which says: V. Rosen. 'A Book of Prayers' (This title is in Arabic).

5. Rasa'il-i-Babiyyih. No. 3078 (A 184)-AMS. It has $149 \mathrm{ff}$. A volume of epistles in Arabic and Persian. Some of the texts are similar to prayers. It is registered in AMS under the title: Rasa'il-i-Babiyyih.

The manuscript is incomplete: the end is missing.

An explanatory note by Rosen, similar to the previous manuscript: "Brought by L.P. Grigoriev from Astrabad in Sept. 1892".

Baha'u'llah's authorship of the volume is beyond any doubt. This is obvious not only from the language and style but also from a reference in one of the texts to the Lawh-i-Ra'is: Baha'u'llah reminds the addressee of the prophecy He made in that Tablet concerning the downfall of the Ottoman Empire:

"Look at the kingdom of Rum. For it did not desire war, however, it was desired by the like of you. Therefore its flames were fanned and its inflammation rose. The government and religion grew weak as was witnessed by every fair-minded observer. Its calamities increased until its smoke covered the Land of Mystery (Adrianople) and the surrounding areas, so that what God hath sent down in the Lawh-i-Ra'is may appear. Thus, God's command in the Book from God, the All-Protecting, Unchangeable, was fulfilled".

\section{Published Manuscripts:}

\section{A. The Writings of Baha'u'llah}

1. Kitab-i-Aqdas (The Most Holy Book) - the major Baha'i scripture, the importance of which for Baha' is is not limited to just the laws and ordinances that Baha'u'llah set forth in it.

In the IOM collection, there are three manuscripts of the Kitab-i-Aqdas, all in an excellent state of preservation. None of them, however, can be identified as the one used by Tumanski for the publication and translation into Russian of this book (see below).

a. No. 3073 (A 460)-AMS. Consists of 45 ff. Dated 1300 A.H. (188283 A.D.), as is indicated at the end of the manuscript. It does not include the last verse, containing the prohibition on the use of opium ("It hath been forbidden you to smoke opium"). 
The manuscript was described by Rosen. ${ }^{25}$

The last page carries a postscript containing a dedication: "This is presented as a gift to his Excellency Matvei Avelievich Gamazoff'. Signed: I. Grigorovich. On 12 July 1888.

A little below, a note signed by Gamazoff says: "Gamazoff delivered it to the Library of the School of Oriental Languages on 6 Sept. [18]88";

b. No. 3074 (A 975)-AMS. Consists of $80 \mathrm{ff}$. The manuscript contains the text of the Most Holy Book in full (including the final verse).

There is a postscript in Persian in the end: "Collated with special care with the new manuscript on 1 Jamadi 1306 A.H. (1888-89 A.D.)".

The last page bears a dedication in Russian: "Presented as a gift to the Library of the School of Oriental Languages by G.D. Batyushkov in 1906".

The fact of its joining the collection so late explains why the manuscript was not described by Rosen.

c. No. 3075 (A 497). Consists of $44 \mathrm{ff}$. Contains the text of the Kitab-iAqdas in full. The text of the The Most Holy Book is followed by a Baha'i marital prayer on 2 pages (which is registered in AMS under a separate sequential number: 3082 ; the code is the same). The manuscript is undated.

The manuscript bears a stamp: Library of the School of Oriental Languages of the Ministry of Foreign Affairs.

A dedicatory note states: "Presented as a gift to the Library of the School of Oriental Languages in 1906".

The original text of the Kitab-i-Aqdas with Russian translation, preceded by a large and very informative introduction, dealing among other things with the history of the Baha'i religion, was published by Tumanski in 1899 .

For the history of this translation and publication it is best to quote an extract from Tumanski's introduction: "Finally, the third volume, which included the "Most Holy Book" - the Kitab-i-Aqdas, which I present now to the reader, was lithographed in 1892 (1308 A.H.) in Bombay and I received the first copies of it in early November 1893. This was during the time when I was finishing the translation of the Kitab-i-Aqdas from the manuscript that I obtained in 1890. Consequently, I felt the need to collate that text with the canonical edition of the Kitab-i-Aqdas. The present publication is based on the latter [canonical] edition, while the differences between this version and my manuscript are marked: my manuscript version is designated by the letter P". ${ }^{26}$ Thus, it follows from this account, Tumanskii first made his translation from his own manuscript, which he then

\footnotetext{
${ }^{25}$ Collections Scientifiques 1891, 144-145 (No. 246).

${ }^{26}$ KITABEAKDES 1899, xxvii-xxviii (translation and italics mine).
} 
collated with the official edition of the text, sent to him in lithographed form, making the latter the basis for his publication of the original text and the final version of his Russian translation of the Most Holy Book. Tumanski also states that his own manuscript has been described by Rosen. ${ }^{27}$ Unfortunately, that information proved incorrect. Consequently, his manuscript is not registered in any catalogue and nothing is now known about it, or about the lithographic edition of the Kitab-i-Aqdas which he used (see also below).

Among the scholarly publications of Baha'i original texts a prominent place is occupied by a large volume of the Tablets and Epistles of Baha'u'llah, prepared for publication from different manuscripts by Rosen, whose sudden death interrupted this work and prevented him seeing the project through. ${ }^{28}$ Its publication, however, was accomplished by Rosen's colleague - Pavel Kokovtsev, who supplied the volume with an introduction, which he modestly titled: "In place of an introduction". In it he provided the reader with some important clues to the history of the volume and its sources. For example, we find out from it that the texts included in the volume were drawn from two manuscripts. One of them (under the code B 1142, see its description below) attracted Rosen's attention back in 1877, when, while making a description of newly acquired manuscripts, he for the first time became closely familiar with the writings of the central figures of the new religion. The above manuscript, presented by Bezobrazoff, consisted of 29 Tablets in Arabic by a writer, named Huseyn (Huseyn 'Ali Nuri = Baha'u'llah), who was at the time unknown to Rosen. One should bear in mind here that, as Tumanski rightly pointed out, knowledge of Baha'u'llah's writings preceded knowledge of Baha'u'llah himself in Russian academic circles (see above). Therefore, it took a great effort on Rosen's part to identify the author of these Tablets and Epistles. Among the latter there was one (No. 20), untitled, as are all the others, that was addressed to the kings, which was later identified as the Tablet/Surih of Kings or the Suriy-i-Muluk. Comparing it with another manuscript, namely that of the Commentary on the Surih of Josef (see above) by the Bab, enabled Rosen to make a tentative, but nonetheless correct conclusion that the author of the Epistle in question "could in no way be the Bab himself, provided the preceding manuscript [i.e., the Commentary on the Surih of Josef] really did come from the pen of

\footnotetext{
${ }^{27}$ Collections Scientifiques 1891, 243.

${ }^{28}$ ROSEN 1908. The volume is available at least in two libraries: the library of IOM and the library of the State University in Kazan (Tatarstan Republic of the Russian Federation). I owe the information about the copy in the University of Kazan to F.L. Sharifullina.
} 
the reformer [i.e. the Bab]". ${ }^{29}$ Later the Library of the Educational Department of Oriental Languages received a new group of writings (manuscript code: A 459, old code: 247, see its description below), among which Rosen discovered another copy of the same Tablet, No. 20 of the earlier manuscript. This time the text was titled: "Suriy-i-Muluk" (Tablet/Surih of Kings). This wondrous find enabled Rosen to identify the author of the Tablet as Baha'u'llah, in spite of Browne's dissenting opinion at that time. Later the prominent British scholar was obliged to accept Rosen's brilliant arguments $^{30}$ and even reproduced them in English in his own article. ${ }^{31}$ This also prompted Rosen to publish the whole manuscript with all the 29 Tablets and Epistles by Baha'u'llah in Arabic. The latter occupy the first half of the volume (the text of the Tablet of Kings was published from both manuscripts, see below), while the second half of the book presents 34 other Epistles of Baha'ullah, including the Tablet of Nasir (Lawh-i-Nasir), from Rosen's own manuscript, which brings the total number of texts in the volume to 63. Unfortunately this last manuscript, which was in Rosen's possession, has still to be found. All we know about it is that it was dated 9 Sha'ban [12]97 A.H. (17 July 1880) and contained 34 Epistles, half of which were in Persian, half in Arabic. The manuscript was untitled, Baha'u'llah's authorship of the Epistles was confirmed by the cryptogram 152 at the end of the manuscript, which equals the numerical value of the name Baha', according to the abjad system. This was also figured out by Rosen. Kokovtsev, who accomplished the publication of the volume after Rosen's death, indicates that the manuscript was given to him for temporary use, through Zhukovski's agency. Thus, before obtaining a titled copy of The Tablet of Kings, Rosen, using convincing arguments, such as the cryptogram $152=$ Baha', similarities of passages between the Tablet of Kings and the Epistle to the Queen of England, from the Alvah-i-Salatin and more, had already proved that the author of the Tablet of Kings was Baha'u'llah.

Rosen also published in full some other Epistles of Baha'u'llah (see below).

2. Untitled MS. No. 3079 (B 1142)-AMS. The manuscript comprises 29 Epistles of Baha'u'llah in Arabic. These form the first part of Rosen's posthumously published volume. ${ }^{32}$ The manuscript consists of $72 \mathrm{ff}$. and includes the Suriy-i-Muluk (beginning on f. 36b).

\footnotetext{
29 "Cet auteur toutefois ne saurait aucunement être le Bâb lui-meme, pourvuque le manuscrit précédent provienne réellement de la plume du réformateur" (Collections Scientifiques 1877, 191).

${ }^{30}$ Collections Scientifiques 1891, 145-149.

${ }^{31}$ BRowne 1892b, 269; 273 (fn.).

${ }^{32}$ Rosen 1908, 1-84.
} 
The manuscript is partial: the last Epistle (No. 29) is incomplete.

It has a note on the first page, half in Russian, half in French: "Don de Mr. Bezobrazov" (Mr. Bezobrazoff's gift).

The manuscript is described in detail by Rosen, ${ }^{33}$ who also quotes the beginning of each Epistleunder the same number as in the published volume. $^{34}$

3. Untitled MS. No. 3079 (A 459)-AMS. The manuscript consists of $182 \mathrm{ff}$. Each text in it is preceded by the cryptogram 152 (indicating the name: Baha' [u'llah]) in red ink.

The manuscript includes the Suriy-i-Muluk (its dating in AMS is incorrect), the title of which appears on the margin in red ink (f. 1b); the Suriy-i-Haykal, including the Alvah-i-Salatin (ff. 40a-154a); the Lawh-i$R a$ 'is (ff. 154a-166a) and some other Epistles, published by Rosen. ${ }^{35}$

The manuscript is beautiful and written in an excellent hand. It is in a very good state of preservation. The last page carries a note in Russian: "I am presenting this as a gift to His Excellency Matvei Avelievich Gamazoff. [Signed:] Grigorovich, 12 July 1888".

Another note below says:

"The Library of the Educational Department, Sept. [18]88. [Signed:] Gamazoff".

4. Untitled MS. No. 3676 (B 1144)-PMS. The manuscript, consisting of $11 \mathrm{ff}$., contains writings of Baha'u'llah in Persian: Lawh-i-Maqsud (ff. 1b9b), and 2 Epistles on the occasion of the tragic events in Ashkhabad, one addressed to Abdu'l-Karim (ff. 9b-10b), the other to "the friends in [different] lands" (ff. 10b-11b). The epistles were published in the original and Russian translation by Tumanski. ${ }^{36}$ The texts of the Epistles were also reproduced in the original by Rosen. ${ }^{37}$ The Lawh-i-Maqsud was not published in its entirety, but was fully described by Rosen, who illustrated his description by large extracts of the text from the manuscript. ${ }^{38}$

The manuscript is in an excellent condition. The Lawh-i-Maqsud is titled, the Epistles are untitled, for which reason they are not mentioned in the catalogues.

5. 'Alvah' No. 433 (Ps II 163). A lithographic volume of some Tablets of Baha'u'llah: The Tablet of Effulgences (Lawh-i-Tajalliyat), The Tablet of

\footnotetext{
${ }^{33}$ Collections Scientifiques 1877, 191-212.

${ }^{34}$ Collections Scientifiques 1877, 200-212.

${ }^{35}$ Collections Scientifiques 1891, 145-243.

${ }^{36}$ TUMANSKI 1892, 317-321.

${ }^{37}$ Collections Scientifiques 1891, 248-250.

${ }^{38}$ Collections Scientifiques 1891, 245.
} 
Splendours (Lawh-i-'Ishraqat), The Tablet of Ornaments (Lawh-i-Tarazat) and The Tablet of the Words of Paradise (Lawh-i-Kalimat-i-Firdawsiyyih). It is recorded in the relevant catalogue as: "Alvah — revelations of Baha'u'llah" (code: Ps II 163). ${ }^{39}$ The date and place of its publication are unknown.

The volume did not serve as an original source for Tumanski's published edition of the same Tablets as supplements to the Most Holy Book (see below), since as Tumanski indicated, he used for his publication a manuscript received in December $1891 .^{40}$

\section{Writings of 'Abdu'l-Baha ${ }^{41}$ (All Lithographs, Except for One Manuscript):}

1. The Secret of Divine Civilization. There are 3 copies of this lithograph in St. Petersburg: 2 in the IOM (listed first), one in the State University:

a. No. 434 (Hd II267). Registered in the relevant catalogue under its Arabic title: Asrar al-Ghaybiyyih li Asbab al-Madaniyyih. ${ }^{42}$ Printed in Bombay in 1299 A.H. (1882 A.D.);

b. No. 435 (Hd I 23). Volume 1 of the same work. Printed in Bombay in 1310 A.H. (1892-93). Registered in the relevant catalogue. ${ }^{43}$

c. No. 168 (O II 1871). Another copy of the same edition. Registered in the relevant catalogue under its Arabic title. ${ }^{44}$

2. A Traveller's Narrative.$^{45}$ There is one manuscript of this text in the IOM and 3 copies of a lithograph: 2 in the IOM (listed first), one in the State University:

a. No. 4186 (B 1147). A manuscript consisting of $100 \mathrm{ff}$. Registered in PMS under its Persian title: Maqaliy-i-Shaxsi Sayyahkidartafsil-i-qaziyyiy-iBab nivishtihast. The title precedes the text of the manuscript.

The front page carries a dedicatory note from Tumanski: "This Babi manuscript 'Tarikh-i-Seyyah (sic)' was sent from Astrabad in 1892 as a gift to the Educational Department by Lieutenant Aleksandr Grigorievich Tu-

\footnotetext{
${ }^{39}$ SHCHEGLOVA 1975, 1: 213.

${ }^{40}$ KITABEAKDES 1899, Supplement III, 72.

41 'Abdu'l-Baha, also known outside the Baha'i community as 'Abbas Effendi (1844 1921) - Baha'u'llah's eldest son. In the Kitab-i-Ahdi (Book of the Covenant), Baha'u'llah named 'Abdu'l-Baha as his successor and the authorized interpreter of his writings.

${ }^{42}$ SHCHEGLOVA 1975, 1: 213-214.

${ }^{43}$ SHCHEGLOVA 1975, 1: 214.

${ }^{44}$ SHCHEGLOVA 1989, 93.

${ }^{45}$ BROWNE 1891.
} 
manski, a graduate of the Oriental languages courses at the Officers' courses of the Department in 1891".

b. No. 435 (Ps II 172). A lithograph. Registered in the relevant catalogue. ${ }^{46}$ Printed in Bombay in 1308 A.H. (1890 A.D.).

c. No. 437 (Pk 637). Another edition of the same text. Registered in the relevant catalogue. ${ }^{47}$ Printed in 1335 A.H. (1917 A.D.). Place of publication unknown.

d. No. 169 (X II 294, П-23/24 - double coding). Another copy of the same edition. Registered in the relevant catalogue under its Persian title. ${ }^{49}$

\section{Other Sources for the History of the Babi and the Baha'i Faiths and for Related Issues:}

A. No. 3351 (C 1885). Registered in PMS under its Persian title: "The Book of Astrabad, Mazinadaran, Gilan, Simnan, Damghan and other [places]".

ff. 55a-58b of this manuscript contain an account of events relating to the Babi movement in the Mazindaran and neighboring areas. The account has a distinct anti-Babi flavor. On ff. 55a, b there is what could be a direct quote from the famous Tahirih (Qurratu'-1 'Ayn).

The manuscript is mentioned by Dorn. ${ }^{50}$

B. No. 495 (B 1145)-PMS. The New History (Tarikh-i-Jadid) by Mirza Husayn Hamadani. ${ }^{51}$ A manuscript of $110 \mathrm{ff}$. The text is incomplete: it breaks off on f. $110 \mathrm{~b} .^{52}$

The manuscript is described by Rosen. ${ }^{53}$ The work itself is dealt with by Tumanski in an article. ${ }^{54}$

C. No. 441 (Hd II 255). The lithograph is registered in the relevant catalogue under its Arabic title: Dala'il al-'Irfan fi Zuhur al-Hujjawa-l-

\footnotetext{
${ }^{46}$ SHCHEGLOVA 1975, 1: 214.

${ }^{47}$ SHCHEGLOVA 1975, 1: 214 .

${ }^{48}$ The first letter of the second code is Cyrillic.

${ }^{49}$ SHCHEGLOVA 1989, 93.

${ }^{50}$ Mélanges Asiatiques 1863, 499 (n. 12).

51 The original text of this work with English translation was published by Browne (BROWNE 1893).

${ }^{52}$ Since the manuscript is incomplete it is impossible to know if it included any mention of the copyist's name and the place where it was copied. Such information normally comes at the end.

${ }^{53}$ Collections Scientifiques 1891, 244.

${ }^{54}$ TUMANSKI 1894.
} 
Tibyan. ${ }^{55}$ The author is Hajj Mirza Haydar 'Ali Isfahani. Printed in Bombay in 1312-13 A.H. (1895 A.D.).

This is a treatise on the appearance of the Mahdi, whom the author identifies with the Bab. The treatise was written in 1310 A.H. (189293 A.D.).

D. No. 440 (Ps I 98). The lithograph is registered in the relevant catalogue under its Persian title: Asas-i-Tarikh-i-Jadid by Mirza Hasan b. MuhammadTaqi Taliqani. ${ }^{56}$

The lithograph was presumably printed in Iran. The place and time of its publication are not mentioned.

As follows from an added note on the cover of the book, it was sent by the author to Zhukovski, through someone named Shubin, in 1915.

E. This manuscript merits a longer description, it is registered in PMS under the code: B 1146, sequential number: 383, title: Bahayiyih. It consists of only $5 \mathrm{ff}$. and contains 5 short texts in Persian:

1. A piece of poetry in honor of His Majesty, the Russian Emperor. The unknown poet, who composed this poem, consisting of 72 verses, expresses his appreciation to the Emperor for the secure life Baha'is were able to lead in Russia;

2. Two poetic pieces, consisting of 19 verses each, by a writer whose pseudonym was either Ruhani or Ruha;

3. A piece of purely religious verse by an unknown poet;

4. A note on the Baha'i law on heritage and the division of the Baha'i year into 19 months;

This has an added note at the end, saying that it was composed at Tumanski request in 1308 A.H.;

5. A note on the chronology of some important events in Babi and Baha' $i$ history, with an explanation of the Baha'i calendar.

It should be noted, that though the explanatory section was written at Tumanski's request by some knowledgeable Baha'i, perhaps Abu-l-Fazl Gulpaygani, this Risalih should not be confused with the Risaliy-iIskandariyyih, consisting of 35 pages, written by Gulpaygani for Tumanskii and mentioned by the latter in the article referred to above.

The manuscript is described in detail by Rosen. ${ }^{57}$

F. No. 442 (Pu 174). The lithograph is registered in the relevant catalogue under its Persian title: Burhan-i-Lami ${ }^{58}{ }^{5}$ Its author is Gulpaygani. Written in

\footnotetext{
${ }^{55}$ SHCHEGLOVA 1975, 1: 216.

${ }^{56}$ SHCHEGLOVA 1975, 1: 215.

${ }^{57}$ Collections Scientifiques 1891, 251-252 (No. 250).
} 
1330 A.H. (1911 A.D.) in Syria. Printed in Chicago (Press of Baha'i News) with an English translation and a portrait of 'Abdu'l-Baha.

This is a polemic work in response to an article by the Protestant missionary Peter Z. Easton published in the magazine "Evangelical Christendom".

G. Majmu'ih. No. 3853 (A 716)-PMS. A manuscript of $18 \mathrm{ff}$. with poetry in Persian, registered in PMS under the title: Majmu'ih. The catalogue describes it in the following way: "The volume contains two short masnavis, a fragment of a masnavi and two qasidas... The first [masnavi] has 182 verses, the second - 212 verses... The manuscript is dated 20 Sha ban 1270 A.H. (1853-54 A.D.]. Probably, the [second] masnavi is titled 'Saha'if"'.

This dating is obviously derived from the note added on the last page (f. 18b), written in a hand different from the poetic text itself. The note, addressing "God's people", calls on them to peruse and know the worth of "these pages" (saha'if, varaqat), for, it says, "the day of the greatest testimony is close" (yawm-i-shahadat-i-akbarnazdikast). It also mentions the day on which the manuscript was finished: Thursday, the twentieth day of the month of Sha ban, year 127? The last figure seems to be missing or at least poorly visible. It seems highly unlikely that the year 1270 A.H., corresponding to 1853-54 A.D. could be the correct date. The main theme of the poetry in the volume is bringing glad tidings of and rejoicing at [the revelation] of Baha, whose "visible countenance has arisen" and who "has torn asunder the veils". These metaphors as well as the subject itself are more relevant to the time after the declaration by Baha'u'llah of his mission in 1279 A.H. (1863 A.D).

Some verses are preceded by introductory notes and admonishments.

Attached to the manuscript is a sheet of paper enclosed in an envelope bearing a prayer to be said during the washing of the hands. The sheet is signed (in Persian): "A scribe... of 'Abdu'l-Baha Husayn". The word, immediately following 'scribe', which could be an epithet, is unclear.

The year that the manuscript joined the collection is mentioned in another note: 1917.

H. No. $443(\mathrm{Pu} \mathrm{10)}$. This is a lithographic volume of Tablets (Lawhs) of Baha'u'llah, compiled by Siyyid Jalal b. HazratSina. The volume is without a title. Printed in Tashkent in 1336 A.H. (1918 A.D.) by the "Idariy-iVahdat". Registered in the relevant catalogue. ${ }^{59}$

\footnotetext{
${ }^{58}$ ShCHEGLOVA 1975, 1: 216.

${ }^{59}$ SHCHEGLOVA 1975, 1: 216.
} 
I. No. 170 (П-23/4). ${ }^{60}$ State University. The lithograph, consisting of 112 pages, is registered in the relevant catalogue under its Persian title: ' $A k k a$ '- $i$ Firgh ${ }^{61}$ Printed in 1311 A.H. (1894 A.D.) presumably in Bombay.

This is a treatise by an anonymous Baha'i writer concerning Islam and the contemporary world. The man indicated as the copyist is "bandiy-i Bab [va] Baha-Mishkinqalam".

Unfortunately, some of the manuscripts published earlier or used for publications in pre-revolutionary Russia have not been found. This is the case with most manuscripts that were in Tumanski's or Rosen's private possession. We know of the existence of such manuscripts from the fact of their being published or mentioned in different publications. Below is a list of those publications:

A. Baha'u'llah's Epistle: Lawh-i-bisharat (The Glad Tidings Epistle), published by Rosen. ${ }^{62}$

B. The manuscript of Baha'u'llah's Epistles in Arabic, included by Rosen in the published volume of Epistles. The manuscript is mentioned in the introduction to the volume (see above).

C. Tumanski's manuscript of the Most Holy Book (Kitab-i-Aqdas), which he used together with the lithographic version for the publication of the original text and its Russian translation (see above). The lithograph has not been found either.

D. The Tablets of Baha'u'llah published by Tumanski ${ }^{63}$ as supplements to the Most Holy Book:

1. The Tablet of 'Ali (Lawh-i-'Ali) - Suppl. 2;

2. The Tablet: The Simplest of Essence (Lawh-i-Basitu'l-Haqiqa)Suppl. 2;

3. The Tablet of Splendours (Lawh-i-Ishraqat) ${ }^{64}$ - Suppl. 3;

4. The Tablet of Ornaments (Lawh-i-Tarazat) - Suppl. 3;

5. The Tablet of Effulgences (Lawh-i-Tajalliyat) ${ }^{65}$ - Suppl. 3;

6. The Tablet of the Words of Paradise (Lawh-i-Kalimat-i-Firdawsiyyih) ${ }^{66}$ Suppl. 3

${ }^{60}$ The letter of the code is in Cyrillic.

${ }^{61}$ ShCheglova 1989, 94.

${ }^{62}$ ROSEN 1893, 183-192. For more details about this Epistle see BUCK and IOANNESYAN 2010, 3-28.

${ }^{63}$ See reference to the manuscript in KITABEAKDES 1899, Supplement III, 72.

${ }^{64}$ This Tablet was addressed to Jalil-i-Khu'i (see MOMEN 1989, 122).

${ }^{65}$ This Tabletwas revealed in honor of Ustad 'Ali-Akbar, a martyr of Yazd (see MomEN 1989, 221). 
E. The Will and Testament of Baha'u'llah, published by Tumanski under the title: Kitab-i-Ahdi (The Book of My Testament). ${ }^{67}$

G. Certain texts from Bakulin's archive, including one attributed to the Bab. These materials were published by Zhukovski in an article. ${ }^{68}$

H. The Jani History (Tarikh-i-Jani) manuscript, owned by Tumanski, containing an episode that is missing in Browne's manuscript of the same work. The episode describes how Baha'u'llah volunteered to take upon himself the blows intended for his younger half-brother MirzaYahya to save the latter from flogging when they were both arrested. The episode with a reference to this manuscript was published by Tumanski in an article. ${ }^{69}$

\section{Conclusion}

The chief imperative for pre-revolutionary Russian scholars who observed the advents of both the Babi and Baha'i faiths was to deeply study and comprehend these new phenomena. The rich collection of materials that they brought together were all accumulated during the decades prior to the Bolshevik takeover in 1917. Pre-revolutionary researchers should also be acknowledged for their scholarly approach, which contributed greatly to the value of their researches and publications that have preserved their significance to this day. Unfortunately, this balanced scholarly approach to religious studies was replaced by an extremely politicized one during Soviet times. Religion in general was considered "the opium of the people" and it could only be approached in a highly biased and negative manner, so the conclusion to be arrived at in the course of a scholarly study was predetermined from the outset. These circumstances detracted a lot from the motivation of scholars interested in the subject, since thorough research of any original material on religion lost much of its significance, while at the same time the publication of primary sources became pointless. Consequently, from 1918 onwards these materials were practically ignored. This does not, however, mean that they were not properly cared for. On the contrary, in all the centers of learning in the former Soviet Union, manuscripts and lithographs, regardless of their content, were always provided with the best possible conditions for their preservation. In general, the

\footnotetext{
${ }^{66}$ This Tablet was revealed by Baha'u'llah in honor of Haji MirzaHaydar-'Ali (see MOMEN 1989, 126)

${ }^{67}$ TUMANSKI 1893, 193-203.

${ }^{68}$ ZHUKOVSKI 1917, 33-90.

${ }^{69}$ TUMANSKI 1894, 33-45.
} 
situation regarding scholarly research started to change in the late 1980s and early 1990s. Now much can be done in the field of religious studies in general and that of Babi and Baha'i studies in particular, so this collection will be of great importance to present and future scholars.

\author{
Abbreviations \\ AMS - The Arabic manuscripts Catalogue (KHALIDOv 1986) \\ JRAS - Journal of the Royal Asiatic Society of Great Britain and Ireland \\ IOM - Institute of Oriental Mansucripts of the Russian Academy of Sciences \\ MS - manuscript \\ PMS - The Persian manuscripts Catalogue (AKIMUSHKIN 1998) \\ ZAN - Zapiski Akademii Nauk [Bulletin of the Academy of Sciences] \\ ZVORAO - Zapiski Vostochnogo Otdeleniia Rossiiskogo Arkheologicheskogo Obschestva \\ [Proceeding of the Oriental Branch of the (Imperial) Russian Archaeological Society].
}

\title{
References
}

AKIMUSHKIN O.F. et al. 1998: Persidskie i tadzhikskie rukopisi Instituta vostokovedeniia Rossiiskoi Akademii nauk [Persian and Tajiki manuscripts of the Institute of Oriental Studies of the Russian Academy of Sciences], vol. 1-2, 2nd ed., New York: Norman Ross Publishing Inc.

BAHA'U'LlAH 2001: Kitáb-i-Íqán [The Book of Certitude]. An academic translation from the original Persian into Russian, with an introduction, commentaries and a textological supplement by Yu.A. Ioannesyan. St. Petersburg: Peterburgskoe Vostokovedenie.

Browne, Edward Granville 1889: "The Bábis of Persia". JRAS (New Series) 21 (1889), 485527; 881-1009.

BROWNE, Edward Granville 1891: A Traveller's Narrative Written to Illustrate the Episode of the Báb. Edited in the Original Persian, and Translated into English, with an Introduction and Explanatory Notes by E.G. Browne, vol. 1-2, London/Cambridge: Cambridge University Press.

BRowne, Edward Granville 1892a: "Catalogue and Description of 27 Bábí Manuscripts". JRAS 24 (1892), 433-499; 637-710.

Browne, Edward Granville 1892b: "Some Remarks on the Bábí Texts edited by Baron Victor Rosen in Vols. I and VI of the Collections Scientifiques de l'Institut des Langues Orientales de Saint-Pétersbourg". JRAS 24 (1892), 259-335.

Browne, Edward Granville 1893: The Tárikh-i-Jadid or New History of Mirzá 'Ali Muhammad the Báb, by Mirzá Huseyn of Hamadan. Translated from the Persian with an Introduction, Illustrations and Appendices by E.G. Browne. London/Cambridge: Cambridge University Press.

BUCK, Christopher and IOANNESYAN, Youli 2010: "Bahá’u'lláh's Bishárát (Glad-Tidings): A Proclamation to Scholars and Statesmen". Baha'i Studies Review 16 (2010). Bristol: Intellect, PO BOX 86, 3-28.

Collections Scientifiques de l'Institut des Langues Orientales du Ministère des Affaires Etrangères 1877-1891. Décrits par M.M. Günzburg, V. Rosen, B. Dorn, K. Patkanov, J. Tchoubinov, vol. I (1877): Les Manuscrits Arabes, vol. III (1886): Les Manuscrits Persan, vol. VI (1891): Les Manuscrits Arabes. St.-Pétersbourg: Imprimerie de l'Académie. 
KHALIDOV A.B. (ed.) 1986: Arabskie rukopisi Instituta vostokovedeniia Akademii Nauk SSSR. Kratkii katalog [A concise catalogue of the manuscripts in Arabic, kept at the Institute of Oriental Studies of the Soviet Academy of Sciences], vol. 1-2, Moscow: Nauka, GRVL.

Kitabe Akdes. Svyaschenneishaya Kniga Sovremennykh Babidov 1899: [The Kitab-i-Aqdas, the Most Holy Book of the Present-day Babis]. Text, Translation, Introduction, Supplements by A.G. Tumanski. ZAN 3 (1899). St. Petersburg: Imperial Academy of Sciences.

Mélanges Asiatiques tirés du Bulletin de l'Académie impériale des sciences de St.-Pétersbourg 1863-1876, vol. 4 (1863), vol. 5 (1868), vol. 7 (1876).

Momen, Wendi 1989: A Basic Baha'i Dictionary. Oxford: George Ronald.

Nicolas, Louis Alphonse Daniel (A.-L.-M.) 1905: Seyyèd Ali Mohammed dit le Bâb. Paris: dujarric \& $\mathrm{C}^{\mathrm{ie}}$.

Rosen V.R. (ed.) 1908: Pervyi Sbornik Poslaniy Babida Behaullaha [First volume of epistles of Baha'u'llah, the Babi]. St. Petersburg: Imperial Academy of Sciences.

Rosen V.R. 1890: "Novye Babidskie Rukopisi” [New Babi Manuscripts]. ZVORAO 4 (1890). St. Petersburg: Imperial Academy of Sciences, 112-114.

Rosen V.R. 1893: "Poslanie BlagieVesti [The glad tidings epistle]. ZVORAO 7 (1893). St. Petersburg: Imperial Academy of Sciences, 183-192.

SHCHEGLOVA O.P. 1975: Katalog litografirovannykh knig na persidskom iazyke v sobranii Leningradskogo otdelenia Instituta vostokovedeniia AN SSSR [A catalogue of the lithographed books in the collection of the Leningrad Branch of the Institute of Oriental Studies of the Academy of Sciences of the USSR], vol. 1-2, Moscow: Nauka.

SHCHEGLOVA O.P. 1989: Katalog litografirovannykh knig na persidskom iazyke v sobranii Vostochnogo otdela nauchnoi biblioteki Leningradskogo gos. universiteta [A catalogue of the lithographed books in the collection of the Oriental Department of the Scholarly Library of Leningrad State University]. Moscow: Nauka.

TUMANSKI A.G. 1892: "Dva poslednikh Babidskikh Otkroveniia" [Two recent Babi revelations]. ZVORAO 6 (1891), 317-321.

TUMANSKI A.G. 1893: "Poslednee Slovo Bahaulli” [Baha'u'llah's last word]. ZVORAO 7 (1893). St. Petersburg: Imperial Academy of Sciences, 193-203.

TUMANSKI A.G. 1894: "K voprosu ob avtorakh istorii Babidov izvestnoi pod imenem Táríkh-i-Mánukchi ili Táríkh-i-Jadíd" [On the question of the authorship of the history of the Babis known as Táríkh-i-Mánukchi تاريخ مانكجى or Táríkh-i-Jadíd تاريخ جديد. ZVORAO 8 (1894), 33-45.

ZHUKOVSKI V.A. 1917: "Rossiiskii imperstorskii konsul F.A. Bakulin v istorii izucheniia Babizma" [Russia's imperial consul F.A. Bakulin in the history of Babi studies]. ZVORAO 24 (1917), 33-90. 